\title{
The Effects of P-Hydroxycinnamic Acid in Ameliorating Spatial Learning and Flexibility Deficits in Rats with Chronic Cerebral Hypoperfusion
}

(Kesan Asid P-Hidroksisinamik dalam Meningkatkan Pembelajaran Reruang dan Defisit Kefleksibelan pada Tikus dengan Hipoperfusi Serebrum Kronik)

\author{
NATSUDA MANYAGASA \& WACHIRYAH THONG-ASA*
}

\begin{abstract}
Cerebral blood reduction resulting in oligemic energy failure and metabolic insufficiency initiates gradual neurodegeneration and cognitive impairments. We investigated the neuroprotective effects of $\mathrm{p}$-hydroxycinnamic acid $(\mathrm{pHCA})$ on neurodegeneration in association with cognitive impairments in rats with chronic cerebral hypoperfusion $(\mathrm{CCH})$. Forty male Sprague-Dawley rats were randomly divided into 4 groups: Sham-veh, 2VO-veh, $2 \mathrm{VO}$-pHCA5O and 2VO-pHCA100. We used modified 2-vessel occlusion (2VO) to induce CCH, and the 2 latter groups were given $50 \mathrm{mg} /$ $\mathrm{kg}$ and $100 \mathrm{mg} / \mathrm{kg}$ of $\mathrm{pHCA}$ after the $2 \mathrm{VO}$ operation, respectively, which continued for 3 weeks. The behavioral tests consisted of anxiety-like behavior tested in an elevated plus maze (EPM) and hippocampal-dependent spatial learning and flexibility tested in a Morris water maze (MWM). Brain oxidative status, infarction, vulnerable hippocampus and corpus callosum (CC) white matter degeneration were evaluated. The results showed that modified 2 VO induced reversible shortterm anxiolytic-like behavior in the EPM $(p<0.05)$. Brain tissue analysis showed that modified 2 VO induced gradual change to brain oxidative status ( $p>0.05)$ with significance infarction, vulnerable hippocampal CA1, CA3, DG and CC degeneration $(p<0.05)$. These were found along with significant spatial learning and flexibility deficits $(p<0.05)$. Additionally, $100 \mathrm{mg} / \mathrm{kg}$ of pHCA significantly ameliorated the spatial learning and flexibility deficits, which coincided with the significant decreases of infarction volume, $C A 1, C A 3$ and $C C$ degeneration $(p<0.05)$. We conclude that $\mathrm{pHCA}$ 's improving effects on spatial learning and flexibility deficits are neuroprotective against oligemic energy failure-induced vulnerable neuronal and white matter degeneration in CCH rats.
\end{abstract}

Keywords: Bilateral common carotid artery occlusion; chronic cerebral hypoperfusion; learning flexibility; modified 2VO; p-hydroxycinnamic acid; spatial learning; water maze

\section{ABSTRAK}

Pengurangan darah serebrum yang mengakibatkan kegagalan tenaga oligemik dan kekurangan metabolik merupakan permulaan neurodegenerasi saraf secara beransur-ansur dan merupakan masalah kognitif. Kami mengkaji kesan neuropelindung asid p-hidroksisinamik (pHCA) pada degenerasi saraf yang berkaitan dengan masalah kognitif pada tikus hypoperfusion cerebral kronik (CCH). Tikus Sprague-Dawley jantan empat puluh ekor secara rawak dibahagikan kepada 4 kelompok, iaitu Sham-veh, 2VO-veh, 2VO-pHCA50 dan 2VO-pHCA100. Kami menggunakan modul dua haluan kapal (2VO) untuk induksi CCH, dan kedua-dua kelompok terakhir diberikan pHCA 50 mg./kg. dan 100 mg./ kg. selepas 2 VO beroperasi dan berterusan selama 3 minggu. Ujian tingkah laku terdiri daripada tingkah laku seperti kecemasan dalam lorongan keliru atas terbaik (EPM) dan pembelajaran reruang yang bergantung pada hipokampal dan kefleksibelan dalam lorongan keliru air Morris (MWM). Status oksidatif otak, otot, hipokampus dan korpus kalosum (CC) degenerasi bahan putih yang dinilai. Hasil menunjukkan bahawa 2 VO diubah suai yang disebabkan oleh tingkah laku seperti anziolisis jangka pendek yang boleh diterbalikkan dalam EPM ( $p<0.05)$. Analisis tisu otak menunjukkan 2 VO yang diubah suai secara beransur-ansur mengubah status oksidatif otak $(p>0.05)$ dengan infark bererti, hipokampal $C A 1, C A 3, D G$ dan CC degenerasi yang terdedah $(p<0.05)$. Ini ditemui bersama dengan pembelajaran reruang dan defisit kefleksibelan $(p<0.05)$. Kepentingan $\mathrm{pHCA} 100 \mathrm{mg} . / \mathrm{kg}$. meningkatkan pembelajaran reruang dan kekurangan kefleksibelan bertepatan dengan penurunan bermakna kelantangan infarksi, CA1, CA3 dan CC degenerasi $(p<0.05)$. Kami menyimpulkan bahawa pHCA meningkatkan kesan terhadap pembelajaran reruang dan defisit kefleksibelan melibatkan perlindungan saraf terhadap kegagalan tenaga oligemik yang disebabkan kemerosotan bahan neuron dan kemerosotan zat putih dalam tikus $\mathrm{CCH}$.

Kata kunci: Asid p-hidroksisinamik; hipoperfusi serebrum kronik; kefleksibelan pembelajaran; lorongan keliru air; oklusi arteri karotid dua hala biasa; pembelajaran reruang; 2VO diubah suai 


\section{INTRODUCTION}

Many cases of neuronal dysfunction disease are caused by the reduction or cessation of cerebral blood flow (CBF), from both normal aging and neurodegenerative diseases (Du et al. 2016). Severely abrupt CBF reduction with or without reperfusion can lead to neuronal and white- matter damages associated with various disabilities (Erkinjuntti 2008; Hou et al. 2002). Mild CBF reduction for a long time period or chronic cerebral hypoperfusion $(\mathrm{CCH})$ can lead to delayed neuronal and white matter damages as well as disability (Bennett et al. 1998; De Jong et al. 1999; de la Torre 2000). The pathomechanisms of $\mathrm{CCH}$ related to degenerations and disabilities can be provided through animal studies using two-vessel occlusion (2VO) to reproduce the $\mathrm{CCH}$ condition. This useful tool provides invaluable knowledge of $\mathrm{CCH}$ in terms of the metabolic changes and neuronal and white matter damages associated with disabilities (Farkas et al. 2007). The outcomes of $\mathrm{CCH}$ following disability come in many forms according to the specific brain area affected. The brain areas vulnerable to CBF reduction, such as the hippocampus, striatum, cortex and corpus callosum (CC), have a pivotal role in cognitive function (Teschendorf et al.2008). Learning, memory and flexibility are the most affected forms of cognition when $\mathrm{CBF}$ is reduced, and they are easy to evaluate in animals by using mazes (Bennett et al. 1998; De Jong et al. 1999; Sarti et al. 2002). These forms of cognition mainly involve the hippocampal neural circuit and its connections with related brain structures (Broadbent et al. 2004; Eichenbaum et al. 1999; Gerlai et al. 2002; Kesner 2000; Moser et al. 2009; Sasaki et al. 2015). Therefore, CCH-induced cognitive impairments coincide with the degree of hippocampal degeneration. Degeneration of the hippocampus and CC was promptly found 2 days after $\mathrm{CCH}$. Such degeneration coincides with learning, memory and flexibility deficits, and the severity gradually increases with time (Otori et al. 2003). CCH also induces psychological behaviors, and one of the most contradictory is anxiety-like behavior. Rats are less anxious when tested in an elevated T-maze (de Bortoli et al.2005) but not less anxious when tested in an EPM (de Wilde et al. 2002). However, these results came from late testing after $\mathrm{CCH}$ onset. Therefore, the present study will confirm whether $\mathrm{CCH}$ induces anxiety-like behavior from early to late $\mathrm{CCH}$ onset.

It is well-known that $\mathrm{CCH}$ induces neurodegeneration via multiple pathomechanisms (Hou et al. 2002), with several pathways for energy-insufficient-induced excitotoxicity, neural inflammation and oxidative damage (Farkas et al. 2007). This is the reason why the interventions are in the form of multidrug therapy (Mehta et al. 2007). One substance may act against a variety of deleterious effects induced by $\mathrm{CCH}$ is $p$-hydroxycinnamic acid $(p \mathrm{HCA})$. It is a hydroxyl-derivative organic compound of cinnamic acid that comes from natural sources, such as peanuts, barley grain, navy beans, tomatoes, carrots, basil, garlic, wine and vinegar (Pei et al. 2015). It exerts a beneficial effect in free oxygen radical scavengers (Tanyeli
2018); improves mitochondrial function by decreasing apoptotic proteins; and increases nuclear respiratory factor (NRF-1), anxiolytic, anti-diabetic, anti-inflammatory, anti-cancer and anti-platelet aggregation (Abdel-Wahab 2003; Amalan 2016; Guven et al. 2015). Recently, a neuroprotective effect against ischemic-reperfusion injury has been found (Sakamula \& Thong-Asa 2018). Currently, the effects of $p \mathrm{HCA}$ on cognitive abilities associated with neurodegeneration have not been studied; therefore, the present study's aim is to investigate the effects of $p \mathrm{HCA}$ against cognitive impairments in rats with $\mathrm{CCH}$ induced by $2 \mathrm{VO}$ in relation to vulnerable neurodegeneration.

\section{MATERIALS AND METHODS}

\section{CHEMICALS AND REAGENTS}

The $p$-hydroxycinnamic acid and other biochemical analysis reagents used in this study were purchased from Chemical Express Co., Ltd. Merck Millipore (Samutprakarn, Thailand).

\section{ANIMALS}

Forty male Sprague-Dawley rats, aged 8 weeks old and weighing 250-300 g, were obtained from the National Laboratory Animal Centre, Mahidol University (Nakornpathom, Thailand). One rat was housed per cage, in a temperature-controlled room $\left(25 \pm 1^{\circ} \mathrm{C}\right)$ on a $12 \mathrm{~h} \mathrm{light/}$ dark cycle, with food and water ad libitum. The procedure was performed under the guidelines of the Principles of Laboratory Animal Care and the Guide of the Care and Use of Laboratory Animals, approved by the National Institutes of Health. The protocol was approved by the Kasetsart University Institutional Animal Care and Use Committee (ID\#ACKU61-SCI-012).

\section{CHRONIC CEREBRAL HYPOPERFUSION}

The rats were randomly divided into 4 groups: Shamveh, 2VO-veh, 2VO-pHCA50 and 2VO-pHCA100. Both common carotid artery occlusions were done as previously described (Cechetti et al. 2010). After fasting, all 2VO rats were anesthetized with an intraperitoneal injection of sodium pentobarbital $(50 \mathrm{mg} / \mathrm{kg})$ plus atropine sulfate $(0.1 \mathrm{mg} / \mathrm{kg})$. A neck ventral midline skin incision was made, and the right common carotid artery was carefully separated from the vagus nerve and permanently occluded with silk suture. The incision was stitched and treated with povidone-iodine solution along with a $5 \mathrm{mg} / \mathrm{kg}$ intramuscular injection of enrofloxacin. Unconscious rats were placed in a recovery chamber under a heat lamp and a blanket until full recovery. One week later, the left common carotid artery occlusion surgery was performed using the same procedures. Sham rats received the same surgical procedures without carotid artery occlusion. Oral administration via gavage feeding was started $24 \mathrm{~h}$ after the second operation. The 2VO- $p \mathrm{HCA} 50$ and 2VO- $p \mathrm{HCA} 100$ 
rats received 50 and $100 \mathrm{mg} / \mathrm{kg}$ of $p \mathrm{HCA}$ dissolved in $10 \%$ Tween 80 (as the vehicle), respectively, which continued for 3 weeks. The Sham-veh and 2VO-veh rats were received only vehicle.

As previous study used $100 \mathrm{mg} / \mathrm{kg}$ body weight of $p \mathrm{HCA}$ and proved the substance has neuroprotective effects against cerebral ischemia. In addition, the dose used in the study also based on preliminary studies with various dose $(50,75,100 \mathrm{mg})$ that proved to be useful (Guven et al. 2015).

\section{SPATIAL LEARNING AND FLEXIBILITY EVALUATION}

After one week of vehicle or $p \mathrm{HCA}$ administrations, the rats were evaluated for sensorimotor function and learningsubordinated skills in the Morris water maze (MWM), which was defined as the cue test. The test consisted of a circular pool $(150 \mathrm{~cm}$ in diameter $)$ with a transparent platform that was exposed $2 \mathrm{~cm}$ over the water surface and located in the center area of the pool. The rats were released into the water to find the platform and given 4 trials with $30 \mathrm{~s}$ inter-trial intervals. Each trial ended when the rat found and climbed onto the platform (120 s time limits for each trial). On the next day, spatial learning ability was tested for 5 consecutive days of acquisition sessions (ACQ) with the same protocol as the cue test, but the platform was submerged $2 \mathrm{~cm}$ below the water surface in the selected target quadrant. The following evaluation of learning flexibility was performed for 3 consecutive days of reversal sessions (REV). In this test, the hidden platform was switched to the opposite quadrant. All of the swimming trials were recorded and analyzed with Smart $^{\odot}$ version 3.0.04 (Planlab Harvard Apparatus). The data were represented as the escape time (s) to find the hidden platform of each session.

\section{ANXIETY-LIKE BEHAVIOR TEST}

The EPM test was carried out once a week (weeks 1,2 and 3 after $\mathrm{CCH}$ ). The apparatus was a black, acrylic, plus-shaped maze elevated $50 \mathrm{~cm}$ above the ground, with 2 opposite closed arms and 2 opposite open arms, separated by a central junction (Plamondon \& Khan 2005). Each rat was placed in the center of the maze facing an open arm and was allowed to freely explore the maze for $5 \mathrm{~min}$. The time spent in and the number of entries into each type of arm were recorded, and anxiety-like behavior was indicated by the percentage of entries into the open arm.

\section{DETERMINATION OF BRAIN OXIDATIVE STATUS}

After the behavioral test, the rats were euthanized with a lethal dose of sodium pentobarbital $(>60 \mathrm{mg} / \mathrm{kg})$. Their brains were removed, and $10 \% \mathrm{w} / \mathrm{v}$ homogenate was prepared in cold phosphate buffer solution (PBS; $0.05 \mathrm{M}$, $\mathrm{pH} 7.4$ ); then, half of the homogenate was centrifuged at $10,000 \times \mathrm{g}$ for $10 \mathrm{~min}$ at $4^{\circ} \mathrm{C}$. The homogenate and the supernatant were stored at $-80^{\circ} \mathrm{C}$ until assay.
The biochemical parameters for assessing brain oxidative status, such as total protein, malondialdehyde (MDA), reduced glutathione (GSH), catalase (CAT) and superoxide dismutase (SOD) activities, were obtained by using the colorimetric method as previously described (Sakamula \& Thong-Asa 2018).

\section{BRAIN INFARCTION ANALYSIS}

The brains were cut in a brain template into 2-mmthick serial coronal sections and stained with $2 \%$ of 2,3,5-triphenyltetrazolium chloride (TTC) at $37^{\circ} \mathrm{C}$ for 10 min and kept in $10 \%$ neutral buffer formalin for $24 \mathrm{~h}$. Brain images were captured for infarction area analysis using NIH ImageJ and represented the whole brain percentage of the infarction area.

\section{NEURODEGENERATION ANALYSIS}

The brains were processed, embedded in paraffin blocks and cut into 5 - $\mu \mathrm{m}$-thick slices using a rotary microtome. Brain sections were collected from the bregma at -2.80 to $-3.80 \mathrm{~mm}$ of stereotaxic reference with an assurance area of the dorsal hippocampus (Paxinos \& Watson 2006). Five sections from each rat were selected, beginning at the bregma at $-3.14 \mathrm{~mm}$ with $125 \mu \mathrm{m}$ intervals. The brain slides were deparaffinized and rehydrated with serial xylene and ethanol (EtOH; 100\% and 95\%, respectively), and then stained with $0.1 \%$ luxol fast blue (LFB) and left overnight in a hot air oven $\left(56^{\circ} \mathrm{C}\right)$. The excessive dye was rinsed off with $95 \% \mathrm{EtOH}$, followed by distilled water. The slides were differentiated in $0.05 \%$ lithium carbonate solution and then in $70 \% \mathrm{EtOH}$, followed by distilled water. The sections were counterstained with $0.1 \%$ cresyl violet solution for $30 \mathrm{~s}$, and excessive dye was rinsed off with distilled water. Then, the sections were dehydrated to serial EtOH (95 and 100\%, respectively) and xylene and closed with cover slides.

The areas of interest for LFB staining were the white matters in the CC. Three images were captured at $200 \times$ magnification using an Olympus Tg300 microscope. The density of myelinated fibers in the CC was then analyzed using NIH Image J and represented as the percentage of LFB area.

For cresyl violet staining, the hippocampal areas of interest were the cornus ammonis (CA) 1 and 3 and the dentate gyrus (DG). Images were captured at $200 \times$ magnification using an Olympus Tg300 microscope. Three captured images of each hemisphere were used to count the number of viable and degenerating cells. Viable cells were characterized by light purple stains in the cytoplasm, with a visible nucleus and nucleolus. Degenerating cells were characterized by cell shrinkage, dark purple staining from the cresyl violet, the disappearance of the nucleolus, and the appearance of vacuoles around the cells (Thong-Asa $\&$ Tilokskulchai 2014). The data were represented as the percentage of degeneration in each area of interest. 


\section{STATISTICAL ANALYSIS}

All data were expressed as mean \pm standard error of the mean (SEM). The escape latency was analyzed by repeatedmeasures ANOVA followed by Fisher's post hoc test. The other variables were analyzed by one-way ANOVA followed by Fisher's post hoc test. Statistical significance was defined as $\mathrm{p}<0.05$.

\section{RESULTS AND DISCUSSION}

None of the rats die after the operations, and they showed no signs of sensorimotor deficit in the mazes. The cue test results, as represented by swim speed (Table 1), showed no significant differences among the groups ( $p>0.05)$. These results indicated that the operation and vessel occlusion did not influence visual and swimming ability in the MWM. Biochemical analysis of the brain tissue showed no differences in any of the assessed parameters $(\mathrm{p}>0.05)$.

Figure 1 shows significant impairment in learning ability during the ACQ and REV sessions in 2VO-veh rats when compared with Sham-veh rats $(\mathrm{p}=0.0005$ and 0.0289 , respectively). Rats treated with $50 \mathrm{mg} / \mathrm{kg}$ and 100 $\mathrm{mg} / \mathrm{kg}$ of $p \mathrm{HCA}$ show significant decrease in escape time in the ACQ session ( $\mathrm{p}=0.0456$ and 0.0108 , respectively). Only $100 \mathrm{mg} / \mathrm{kg}$ of $p \mathrm{HCA}$ showed a significant decrease in escape time in the REV session when compared to the $2 \mathrm{VO}$-veh rats $(\mathrm{p}=0.0128)$. The results indicated that $2 \mathrm{VO}$ can induce both spatial learning and flexibility deficits and that only $100 \mathrm{mg} / \mathrm{kg}$ of $p \mathrm{HCA}$ can improve these cognitive deficits in the MWM.
Figure 2 shows the results of the anxiety-like behavior assessment in the EPM from the first to the third week with $2 \mathrm{VO}$. The results indicated that $2 \mathrm{VO}$ induced reversible anxiolytic-like behavior, as represented by the significantly increased percentage of open arm entry at the first and second weeks when compared to the Sham-veh rats ( $p$ $=0.0116$ and 0.0406 , respectively). The anxiolytic-like behavior was still presented from the first to the second week and disappeared in the third week. Rats treated with $50 \mathrm{mg} / \mathrm{kg}$ and $100 \mathrm{mg} / \mathrm{kg}$ of $p$ HCA showed the same trend as with $2 \mathrm{VO}$ of inducing anxiolytic-like behavior when compare to Sham-veh rats $(\mathrm{p}=0.0023$ and 0.0286 , respectively). That the anxiolytic-like behavior was induced solely by $2 \mathrm{VO}$ was confirmed by the insignificant relationship between $2 \mathrm{VO}$ with or without $p \mathrm{HCA}$ treatment. The whole brain infarction area in Figure 3 indicated that 2VO-veh rats had significantly increased infarction areas. This was represented by the high percentage of infarction in the 2VO-veh rats when compared to the Sham-veh rats $(\mathrm{p}=0.0461)$. Only the $2 \mathrm{VO}-p \mathrm{HCA} 100$ group showed a significant decrease in infarction area when compared to the 2VO-veh group ( $\mathrm{p}=0.0103)$.

The percentage of LFB density in CC was significantly reduced among the 2VO-veh rats compared to the Shamveh rats $(\mathrm{p}<0.0001)$. Rats treated with $50 \mathrm{mg} / \mathrm{kg}$ and 100 $\mathrm{mg} / \mathrm{kg}$ of $p \mathrm{HCA}$ had significantly less LFB density reduction in $\mathrm{CC}$ when compared to the $2 \mathrm{VO}-\mathrm{veh}$ rats $(\mathrm{p}<0.0001$ and $\mathrm{p}<0.0001$, respectively). This finding coincides with the reduction of rarefaction and degenerating oligodendrocytes shown in Figure 4.

TABLE 1 . Swimming ability and brain oxidative status

\begin{tabular}{lcccc}
\hline & Sham-veh & 2VO-veh & 2VO- $p$ HCA50 & 2VO-pHCA100 \\
\hline Swim speed $(\mathrm{cm} / \mathrm{s})$ & $14.79 \pm 1.38$ & $14.34 \pm 1.07$ & $12.95 \pm 0.76$ & $12.38 \pm 0.76$ \\
Protein $(\mathrm{mg} / \mathrm{mL})$ & $4.912 \pm 0.128$ & $4.837 \pm 0.084$ & $4.784 \pm 0.067$ & $4.633 \pm 0.123$ \\
MDA $(\mathrm{mM})$ & $10.268 \pm 2.720$ & $14.336 \pm 3.422$ & $13.314 \pm 0.688$ & $11.449 \pm 2.583$ \\
GSH $(\mathrm{mM})$ & $0.141 \pm 0.012$ & $0.422 \pm 0.011$ & $0.411 \pm 0.014$ & $0.417 \pm 0.009$ \\
CAT $(\mathrm{U} / \mathrm{mL})$ & $11.562 \pm 3.314$ & $13.389 \pm 4.612$ & $18.996 \pm 7.424$ & $22.453 \pm 4.425$ \\
SOD $(\mathrm{U} / \mathrm{mL})$ & $6.346 \pm 0.181$ & $7.125 \pm 1.187$ & $7.688 \pm 0.354$ & $7.351 \pm 1.716$ \\
\hline
\end{tabular}

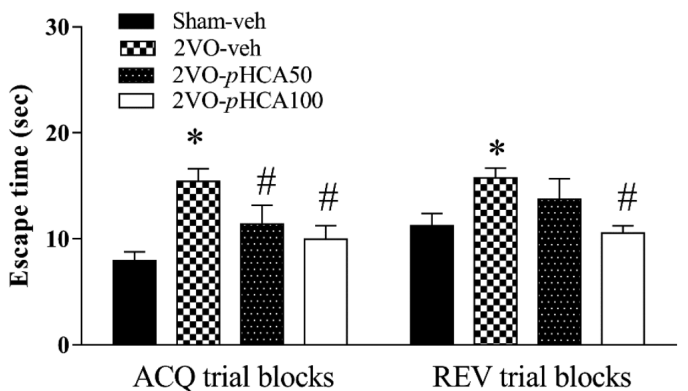

*Indicate significant difference compare to Sham-veh. "Indicate significant difference compare to $2 \mathrm{VO}$-veh

FIGURE 1. Cognitive abilities in acquisition (ACQ) and reversal (REV) learning sessions in the MWM

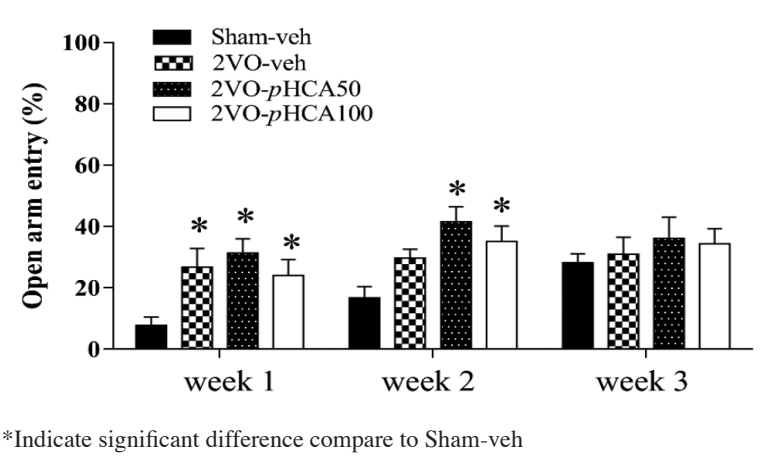

FIGURE 2. The percentage of open arm entry in EPM 


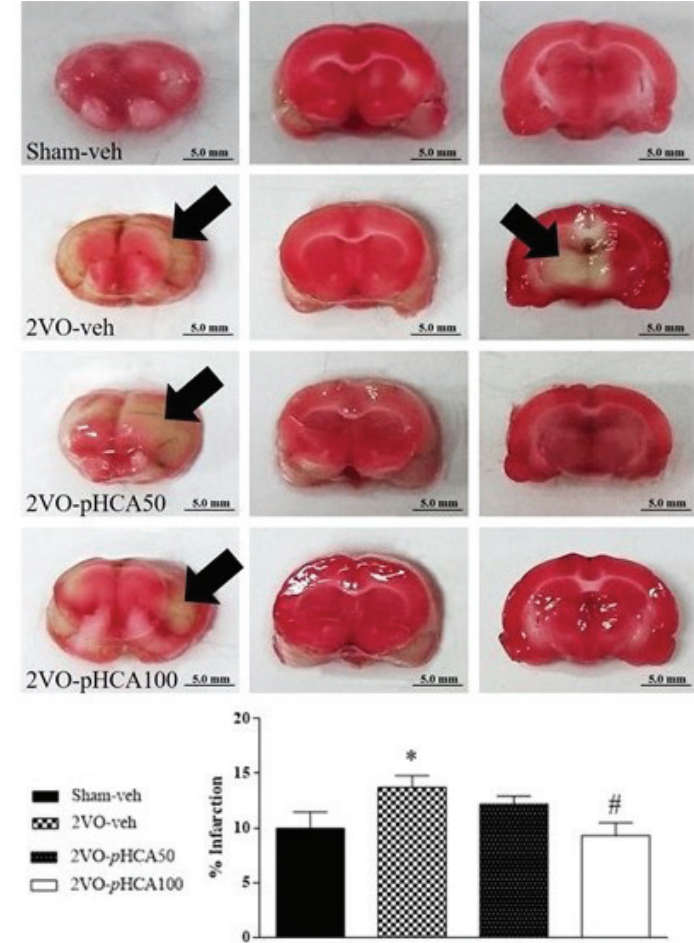

*Indicate significant difference compare to Sham-veh. "Indicate significant difference compare to $2 \mathrm{VO}$-veh

FIGURE 3. Brain sections with TTC staining. Black arrows indicate the infarction area represented by pale tissue color
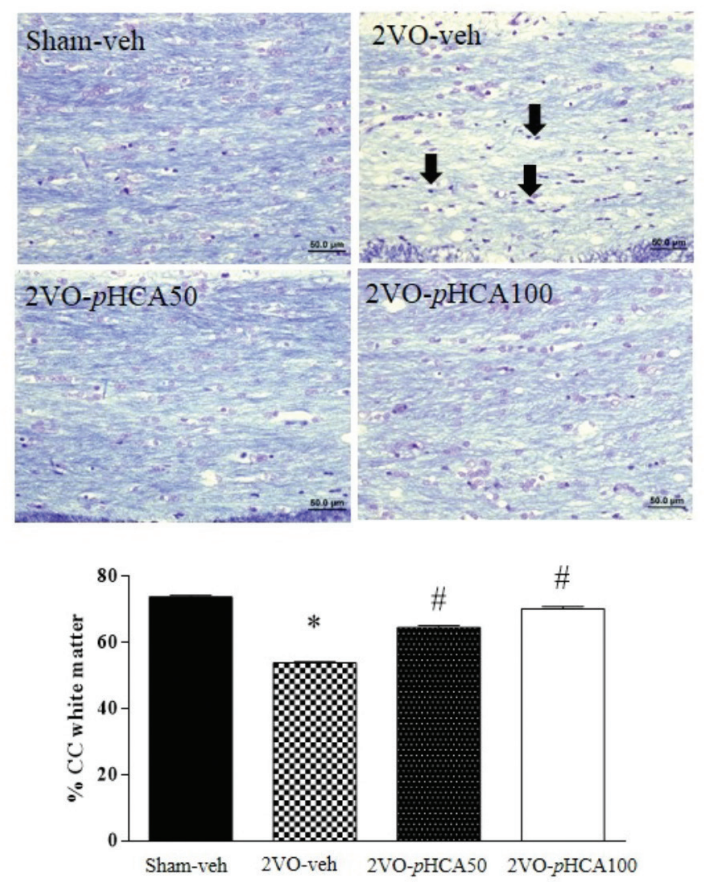

*Indicate significant difference compare to Sham-veh. "Indicate significant difference compare to $2 \mathrm{VO}$-veh

FIGURE 4. The CC white matter with LFB staining.

Black arrows indicate rarefaction area with degenerating oligodendrocytes
The degeneration of vulnerable hippocampal neurons in the CA1, CA3 and DG regions was significantly induced by $2 \mathrm{VO}$ ( $\mathrm{p}=0.0005,0.0001$ and 0.0089 , respectively) (Figures 5-7). Only $100 \mathrm{mg} / \mathrm{kg}$ of $p \mathrm{HCA}$ indicated significant reductions of CA1 and CA3 degeneration ( $\mathrm{p}=$ 0.0186 and 0.0006, respectively) (Figures 5-6). In CA1, though $100 \mathrm{mg} / \mathrm{kg}$ of $p \mathrm{HCA}$ significantly reduced neuronal degeneration, a significant difference from Sham-veh still be presented $(\mathrm{p}=0.0230)$ (Figure 5). In the DG, 2VO rats treated with $p \mathrm{HCA}$ had no statistically significant differences from the Sham-veh or 2VO-veh rats (Figure 7).

The present study demonstrates a beneficial effect of $p \mathrm{HCA}$ against $\mathrm{CCH}$. We found that $100 \mathrm{mg} / \mathrm{kg}$ of $p \mathrm{HCA}$ was an effective dose for neuroprotection and amelioration of cognitive deficits. The induction of $\mathrm{CCH}$ by $2 \mathrm{VO}$ is widely used nowadays, with benefits for reproducing cognitive deficits associated with neurodegeneration (Farkas \& Luiten 2001; Farkas et al. 2006, 2004a, 2004b). However, this model causes a high mortality rate and has benefits for only a short experimental period, when the simultaneous occlusion is performed. In 2010, the modified 2VO model was proposed with similar benefits for pathological induction along with a low mortality rate (Cechetti et al. 2010). When using the modified 2VO model, cognitive deficits are indicated from 28 days to 3 months after operation (Cechetti et al. 2010; Li et al. 2015). The present study used the modified $2 \mathrm{VO}$ model and found
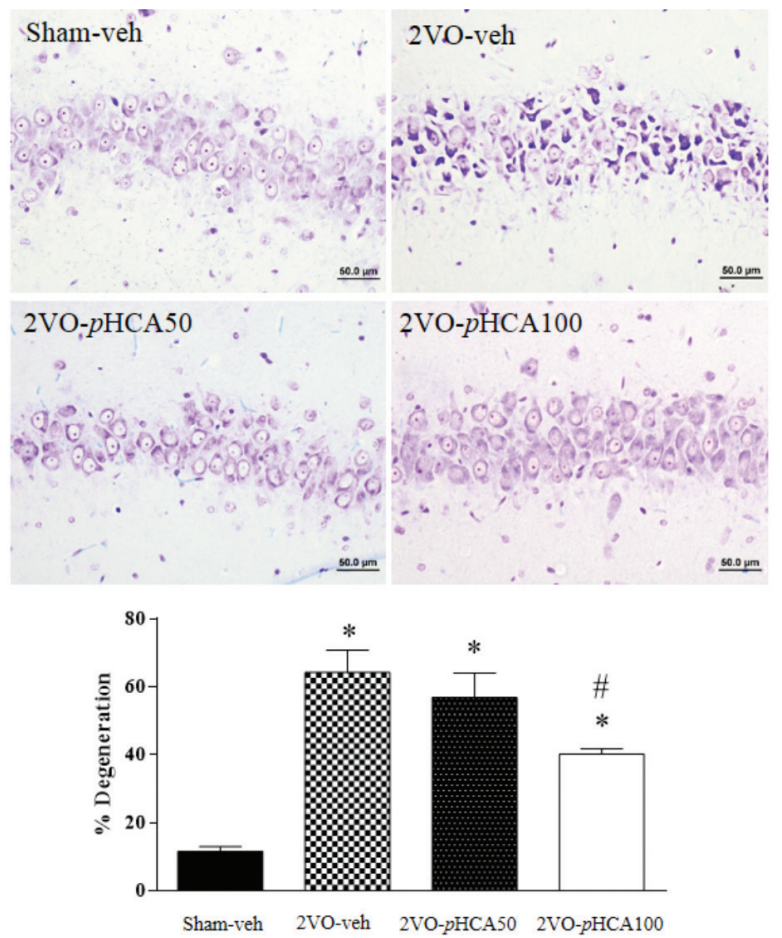

*Indicate significant difference compare to Sham. "Indicate significant difference compare to 2VO-veh

FIGURE 5. Hippocampal CA1 neurons with cresyl violet staining 


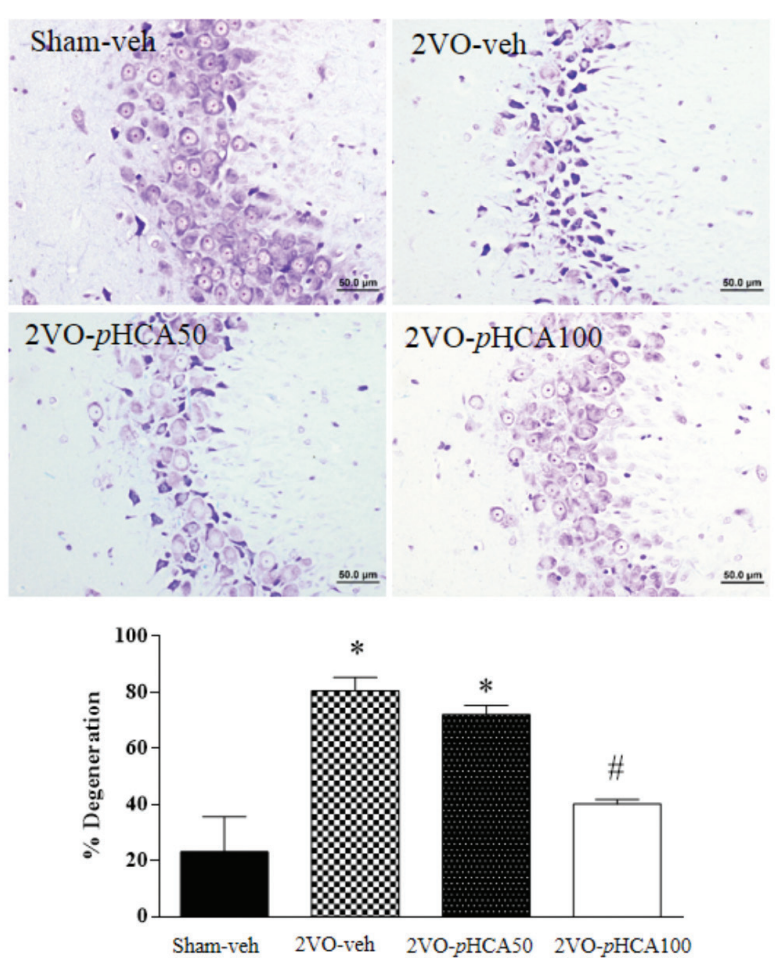

*Indicate significant difference compare to Sham. "Indicate significant difference compare to $2 \mathrm{VO}$-veh

FIGURE 6. Hippocampal CA3 neurons with cresyl violet staining
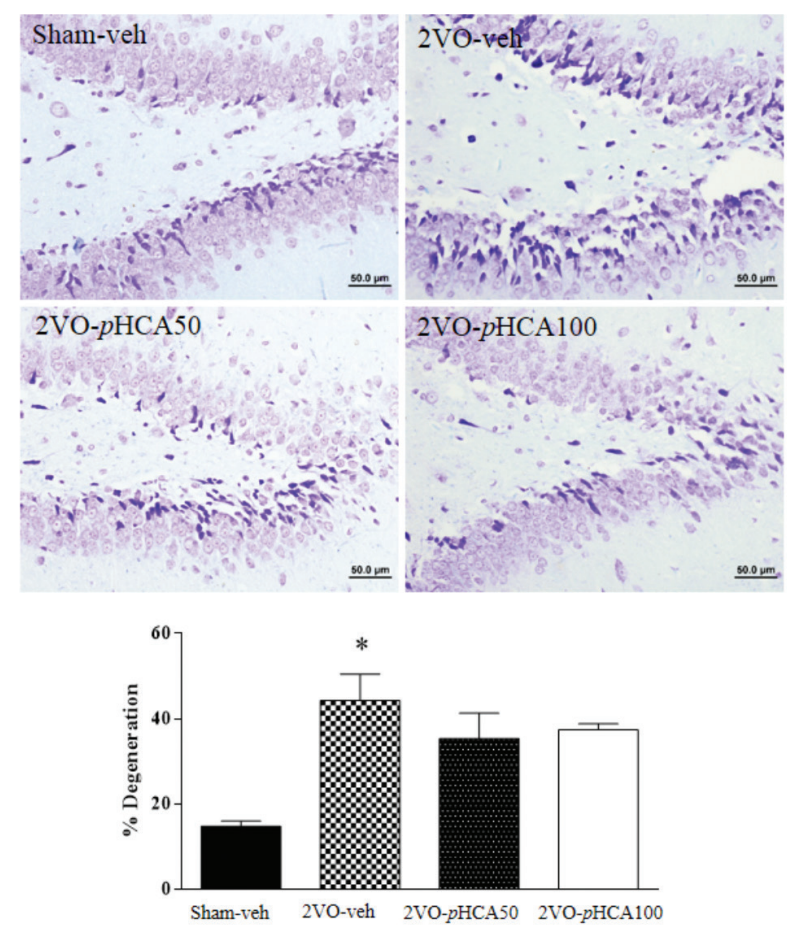

*Indicates significant difference compare to Sham

FIGURE 7. Hippocampal DG neurons with cresyl violet staining that the deficits in spatial learning and learning flexibility were depicted 2-3 weeks after the CCH's onset. Our results confirm early deficits since standard and modified $2 \mathrm{VO}$ were tested (Cechetti et al. 2010; $\mathrm{Li}$ et al. 2015; Liu et al. 2005). These cognitive deficits were found along with significance degeneration of vulnerable CA1, CA3, and DG neurons of the dorsal hippocampus and the CC, which provides additional confirmation of the susceptibility of these areas' neuron and white matter to $\mathrm{CCH}$. In addition, the EPM results of our anxiety-like behavioral test indicated that 2VO induces reversible short-term anxiolytic-like behavior in rats. Unlike in a previous report (de Wilde et al. 2002), in which $2 \mathrm{VO}$ rats did not express anxiety-like behavior in EPM, this study test at the third week after $2 \mathrm{VO}$ onset. Anxiety-like behavior in the present study was tested at the first, second and third weeks after $2 \mathrm{VO}$ onset and we found $\mathrm{CCH}$ significance induce anxiolytic-like behavior in the first week, then it is disappeared at the second and third week in $2 \mathrm{VO}$-veh rats. This is a result of the modified $2 \mathrm{VO}$, which reduced the persistence of $\mathrm{CBF}$ by about $30 \%$ and $20 \%$ at $24 \mathrm{~h}$ to 28 days, respectively, and influenced the neuronal functions ( $\mathrm{Li}$ et al. 2015). The present study's infarction area evaluation found the affected brain areas, such as the cerebral cortex, striatum and hippocampus (Figure 3). These brain areas are responsible for cognitive function and other related brain functions such as sensory, motor and emotional functions. Anxiety is a part of emotional function in the limbic structures' connectivity and can be affected by CBF alterations. Evidence showed that global cerebral ischemia can induce anxiolytic-like behavior in the first week (Yan et al. 2007). This is associated with alterations to the dopaminergic neurotransmitter system along with changes to anxiety-like behavior induced by ischemia (Winter et al. 2005). The temporary presence of anxiolytic-like behavior in the first week may involve this alteration. A significant increase in anxiolytic-like behavior among the $p \mathrm{HCA}$-treated groups was found from the first to the second week, as compared to the Sham-veh rats. The first-week anxiety change may have been the combine effect of $\mathrm{CCH}$ with $p \mathrm{HCA}$, while the second-week difference may have been solely the anxiolytic effect of $p \mathrm{HCA}$ as a receptor agonist on the gamma-aminobutyric acid (GABA) neurotransmitter circuitry (Scheepens et al. 2014). The anxiolytic effect caused by $\mathrm{CCH}$ and $p \mathrm{HCA}$ was temporarily in the present study. Open arm avoidance may have been habituated over repeated trials for the Sham-veh rats, which may have caused a lack of differences in the third-week EPM test (Schrader et al. 2018).

The neuroprotective effects of $p \mathrm{HCA}$ in the present study were represented by the decreases to whole brain infarction and to hippocampal and CC degeneration in the $p \mathrm{HCA}$-treated rats. The decrease of infarction area represented by the aerobic respiration marker, $\mathrm{NADH}$, shows that $100 \mathrm{mg} / \mathrm{kg}$ of $p \mathrm{HCA}$ prevented the increase of pale tissue area. This involves an ameliorative effect of $p \mathrm{HCA}$ on energy failure from the increase in NRF-1 and nuclear gene-encoding respiration protein (Guven et al. 2015), which maintains metabolism and help to 
protect from neurodegeneration and cognitive deficits. $p$ HCA's effect of preventing infarction area expansion also involves improved mitochondrial function by decreasing apoptotic proteins and the anti-inflammatory effects of pHCA (Abdel-Wahab 2003; Amalan 2016), which further contribute to neuroprotection against vulnerable neuronal and white matter degeneration.

Spatial learning and flexibility deficits in the MWM were associated with CA1, CA3, DG and CC damage. In the $\mathrm{CC}$, both 50 and $100 \mathrm{mg} / \mathrm{kg}$ of $\mathrm{pHCA}$ can prevent the decrease of LFB density, rarefaction and oligodendrocyte degenerations, but in vulnerable brain regions such as CA1 and CA3, only $100 \mathrm{mg} / \mathrm{kg}$ was effective. Spatial learning deficits in the ACQ session were improved among rats treated with both 50 and $100 \mathrm{mg} / \mathrm{kg}$ of $p \mathrm{HCA}$. Flexibility deficits in the REV session were improved only by 100 $\mathrm{mg} / \mathrm{kg}$ of $p \mathrm{HCA}$. In considering $p$ HCA's effects on spatial learning improvements and CA 1 and CA3 degeneration, spatial learning requires a minilab of hippocampal volume (Moser et al. 1995). Therefore, the significant degeneration of CA1 and CA3 did not coincide with the intact acquisition function. In reversal learning, only 100 $\mathrm{mg} / \mathrm{kg}$ of $p \mathrm{HCA}$ improved learning flexibility, whereas $50 \mathrm{mg} / \mathrm{kg}$ of $p \mathrm{HCA}$ did not. In addition to $p$ HCA's effects against CA3 degeneration, $100 \mathrm{mg} / \mathrm{kg}$ was effective against histological and functional changes. This indicated more involvement of CA3 in reversal learning than CA1. In fact, both acquisition and reversal learning in the MWM are hippocampal-dependent cognitive types (Morris 1984; Moser \& Moser 1998; Wolfer et al. 1998; Russig et al. 2003), and alterations to the hippocampus produce greater effects on reversal learning than on initial spatial learning due to the differences in the neural circuits for learning and flexibility (Pouzet et al. 1999). The CA1 hippocampal place cells acquire spatial location, with entorhinal grid cells also participating (O'Keefe 1993; O'Keefe \& Conway 1978; O'Keefe \& Dostrovsky 1971). In reversal learning, the neural basis involves the cortical regions, orbitofrontal cortex (OFC), striatal, amygdala (Izquierdo et al. 2016) and hippocampus (Vila-Ballo et al. 2017). It has been shown that CA1 and CA3 cells firing respond differently to familiar versus changed environments (Bahar et al. 2011), and the within- hippocampal circuit (CA1, 3 and DG) contributes differently to distinct aspects of spatial cognition. The within circuit of reversal learning needs more cooperation between CA3 and other local areas (Kesner 2007) together with the frontocorticostriatal circuitry (Izquierdo \& Jentsch 2012). The present study found that only $100 \mathrm{mg} / \mathrm{kg}$ of $p \mathrm{HCA}$ can prevent CA3 degeneration, associated with significant improvement to flexibility deficits in reversal learning. Improving $p$ HCA's effects on cognitive function involves enhancing CA1's long-term potentiation (LTP). The synaptic strengthening is modified by the N-methyl-D-aspartic acid (NMDA) receptor channel and modulations to the central cholinergic neurotransmitter system (Kim et al. 2017).

Regarding the oxidative stress induced by $\mathrm{CCH}$ in neurodegeneration, oligemic energy failure leading to metabolic insufficiency is initiate a variety of deteriorations (Farkas et al. 2007). Brain oxidative stress induction was not clear in the early phase of $\mathrm{CCH}$ in the present study, and biochemical parameters such as protein level, MDA, CAT, SOD and GSH showed no differences. A previous study indicated that changes can be found in the whole brain at 8 weeks after $2 \mathrm{VO}$, which suggested that the changes in brain oxidative status are gradual in the $2 \mathrm{VO}$ model (Saxena et al. 2015). Therefore, the present study cannot claim the effects of $p \mathrm{HCA}$ against brain oxidative stress. However, some evidence implied $p$ HCA's benefits against oxidative stress in severely ischemic conditions (Guven et al. 2015; Sakamula \& Thong-Asa 2018).

\section{CONCLUSION}

We conclude that $p$ HCA's positive effects on spatial learning and flexibility deficits involve neuroprotection against oligemic energy failure, which induces vulnerable neuronal and white matter degeneration in $\mathrm{CCH}$ rats.

\section{ACKNOWLEDGEMENTS}

This research was supported, under the Strengthening and Developing New Researcher Plan, in conformance with the Research and Innovation of Graduate Study Strategy of the National Research Council of Thailand (NRCT) as of the fiscal year 2019. This research was supported by the Graduate Program Scholarship from the Graduate School, Kasetsart University.

\section{REFERENCES}

Bahar, A.S., Shirvalkar, P.R. \& Shapiro, M.L. 2011. Memoryguided learning: CA1 and CA3 neuronal ensembles differentially encode the commonalities and differences between situations. The Journal of Neuroscience 31(34): 12270-12281.

Bennett, S.A., Tenniswood, M., Chen, J.H., Davidson, C.M., Keyes, M.T., Fortin, T. \& Pappas, B.A. 1998. Chronic cerebral hypoperfusion elicits neuronal apoptosis and behavioral impairment. Neuroreport 9(1): 161-166.

Broadbent, N.J., Squire, L.R. \& Clark, R.E. 2004. Spatial memory, recognition memory, and the hippocampus. Proc Natl Acad Sci U S A 101(40): 14515-14520.

Cechetti, F., Worm, P.V., Pereira, L.O., Siqueira, I.R. \& A. Netto, C. 2010. The modified 2VO ischemia protocol causes cognitive impairment similar to that induced by the standard method, but with a better survival rate. Braz. J. Med. Biol. Res. 43(12): 1178-1183.

de Bortoli, V.C., Zangrossi J $\square$ nior, H., de Aguiar Corr $\square$ a, F.M., de Sousa Almeida, S. \& de Oliveira, A.M. 2005. Inhibitory avoidance memory retention in the elevated T-maze is impaired after perivascular manipulation of the common carotid arteries. Life Sciences 76(18): 2103-2114.

De Jong, G.I., Farkas, E., Stienstra, C.M., Plass, J.R.M., Keijser, J.N., de la Torre, J.C. \& Luiten, P.G.M. 1999. Cerebral hypoperfusion yields capillary damage in the hippocampal CA1 area that correlates with spatial memory impairment. Neuroscience 91(1): 203-210. 
de la Torre, J.C. 2000. Critically attained threshold of cerebral hypoperfusion: The CATCH hypothesis of Alzheimer's pathogenesis. Neurobiology of Aging 21(2): 331-342.

de Wilde, M.C., Farkas, E., Gerrits, M., Kiliaan, A.J. \& Luiten, P.G.M. 2002. The effect of n-3 polyunsaturated fatty acid-rich diets on cognitive and cerebrovascular parameters in chronic cerebral hypoperfusion. Brain Research 947(2): 166-173.

Du, S-Q., Wang, X-R., Xiao, L-Y., Tu, J-F., Zhu, W., He, T. \& Liu, C-Z. 2016. Molecular mechanisms of vascular dementia: What can be learned from animal models of chronic cerebral hypoperfusion? Molecular Neurobiology 54: 3670-3682.

Eichenbaum, H., P. Dudchenko, E. Wood, M. Shapiro, and H. Tanila. 1999. The hippocampus, memory, and place cells: is it spatial memory or a memory space? Neuron 23 (2):209-26.

Erkinjuntti, T. 2008. Cerebrovascular disease, vascular cognitive impairment and dementia. Psychiatry 7(1): 15-19.

Farkas, E., Donka, G., de Vos, R.A. Mihaly, A., Bari, F. \& Luiten, P.G. 2004. Experimental cerebral hypoperfusion induces white matter injury and microglial activation in the rat brain. Acta Neuropathol 108(1): 57-64.

Farkas, E., Institoris, A., Domoki, F., Mihaly, A. \& Bari, F. 2006. The effect of pre- and posttreatment with diazoxide on the early phase of chronic cerebral hypoperfusion in the rat. Brain Res. 1087(1): 168-174.

Farkas, E., Institoris, A., Domoki, F., Mihaly, A., Luiten, P.G. \& Bari, F. 2004. Diazoxide and dimethyl sulphoxide prevent cerebral hypoperfusion-related learning dysfunction and brain damage after carotid artery occlusion. Brain Res. 1008(2): 252-260.

Farkas, E., Luiten, P.G.M. \& Bari, F. 2007. Permanent, bilateral common carotid artery occlusion in the rat: A model for chronic cerebral hypoperfusion-related neurodegenerative diseases Brain Research Reviews 54(1): 162-180.

Farkas, E. \& Luiten. P.G.M. 2001. Cerebral microvascular pathology in aging and Alzheimer's disease. Progress in Neurobiology 64(6): 575-611.

Gerlai, R.T., McNamara, A., Williams, S. \& Phillips, H.S. 2002. Hippocampal dysfunction and behavioral deficit in the water maze in mice: An unresolved issue? Brain Res. Bull. 57(1): 3-9.

Guven, M., Aras, A.B., Akman, T., Sen, H.M., Ozkan, A., Salis, O., Sehitoglu, I., Kalkan, Y., Silan, C., Deniz, M. \& Cosar, M. 2015. Neuroprotective effect of p-coumaric acid in rat model of embolic cerebral ischemia. Iran J. Basic Med. Sci. 18(4): 356-363.

Hou, S.T., MacManus, J.P. \& Kwang, W.J. 2002. Molecular mechanisms of cerebral ischemia-induced neuronal death. International Review of Cytology 221: 93-148.

Izquierdo, A., Brigman, J.L., Radke, A.K., Rudebeck, P.H. \& Holmes, A. 2016. The neural basis of reversal learning: An updated perspective. Neuroscience 345: 12-26.

Izquierdo, A. \& Jentsch, J.D. 2012. Reversal learning as a measure of impulsive and compulsive behavior in addictions. Psychopharmacology 219(2): 607-620.

Kesner, R.P. 2000. Behavioral analysis of the contribution of the hippocampus and parietal cortex to the processing of information: interactions and dissociations. Hippocampus 10(4): 483-490.

Kesner, R.P. 2007. Behavioral functions of the CA3 subregion of the hippocampus. Learn Mem. 14(11): 771-781.

Kim, H.B., Lee, S., Hwang, E.S., Maeng, S. \& Park, J.H. 2017. p-Coumaric acid enhances long-term potentiation and recovers scopolamine-induced learning and memory impairments. Biochem. Biophys. Res. Commun. 492(3): 493-499.

Li Nan, Gu Zhiqiang, Li Yunfei, Fu Xiaojie, Wang Jianping \& Bai Hongying. 2015. A modified bilateral carotid artery stenosis procedure to develop a chronic cerebral hypoperfusion rat model with an increased survival rate. Journal of Neuroscience Methods 255: 115-121.

Liu, H.X., Zhang, J.J., Zheng, P. \& Zhang, Y. 2005. Altered expression of MAP-2, GAP-43, and synaptophysin in the hippocampus of rats with chronic cerebral hypoperfusion correlates with cognitive impairment. Brain Res. Mol. Brain Res. 139(1): 169-177.

Mehta, S.L., Manhas, N. \& Raghubir, R. 2007. Molecular targets in cerebral ischemia for developing novel therapeutics. Brain Research Reviews 54(1): 34-66.

Morris, R. 1984. Developments of a water-maze procedure for studying spatial learning in the rat. Journal of Neuroscience Methods 11(1): 47-60.

Moser, E.I., Moser, M.B. \& Squire, L.R. 2009. Hippocampus and Neural Representations. In Encyclopedia of Neuroscience. Oxford: Academic Press.

Moser, M.B. \& Moser, E.I. 1998. Functional differentiation in the hippocampus. Hippocampus 8(6): 608-619.

Moser, M.B., Moser, E.I., Forrest, E., Andersen, P. \& Morris, R.G. 1995. Spatial learning with a minislab in the dorsal hippocampus. Proc. Natl. Acad. Sci. USA 92(21): 9697-9701.

O'Keefe, J. 1993. Hippocampus, theta, and spatial memory. Curr. Opin. Neurobiol. 3(6): 917-924.

O'Keefe, J. \& Conway, D.H. 1978. Hippocampal place units in the freely moving rat: Why they fire where they fire. Exp. Brain Res. 31(4): 573-590.

O'Keefe, J. \& Dostrovsky, J. 1971. The hippocampus as a spatial map. Preliminary evidence from unit activity in the freelymoving rat. Brain Res. 34(1): 171-175.

Otori, T., Katsumata, T., Muramatsu, H., Kashiwagi, F., Katayama, Y. \& Terashi, A. 2003. Long-term measurement of cerebral blood flow and metabolism in a rat chronic hypoperfusion model. Clin. Exp. Pharmacol. Physiol. 30(4): 266-272.

Paxinos, G. \& Watson, C. 2006. The Rat Brain in Stereotaxic Coordinates. 6 ed. Massachusetts: Academic Press.

Pei, K., Ou, J., Huang, J. \& Ou, S. 2015. p-Coumaric acid and its conjugates: Dietary sources, pharmacokinetic properties and biological activities. J. Sci. Food Agric. 96(9): 2952-2962.

Plamondon, H. \& Khan, S. 2005. Characterization of anxiety and habituation profile following global ischemia in rats. Physiology \& Behavior 84(4): 543-552.

Pouzet, B., Welzl, H., Gubler, M.K., Broersen, L., Veenman, C.L., Feldon, J., Rawlins, J.N. \& Yee, B.K. 1999. The effects of NMDA-induced retrohippocampal lesions on performance of four spatial memory tasks known to be sensitive to hippocampal damage in the rat. Eur. J. Neurosci. 11(1): 123-140.

Russig, H., Durrer, A., Yee, B.K., Murphy, C.A. \& Feldon, J. 2003. The acquisition, retention and reversal of spatial learning in the morris water maze task following withdrawal from an escalating dosage schedule of amphetamine in wistar rats. Neuroscience 119(1): 167-179.

Sakamula, R. \& Thong-Asa, W. 2018. Neuroprotective effect of $\mathrm{p}$-coumaric acid in mice with cerebral ischemia reperfusion injuries. Metab. Brain Dis. 33(3): 765-773.

Sarti, C., Pantoni, L., Bartolini, L. \& Inzitari, D. 2002. Cognitive impairment and chronic cerebral hypoperfusion: What can 
be learned from experimental models. J. Neurol. Sci. 203204: 263-266.

Sasaki, T., Leutgeb, S. \& Leutgeb, J.K. 2015. Spatial and memory circuits in the medial entorhinal cortex. Current Opinion in Neurobiology 32: 16-23.

Saxena, A.K., Saif Saad Abdul-Majeed, Gurtu, S. \& Mohamed, W.M.Y. 2015. Investigation of redox status in chronic cerebral hypoperfusion-induced neurodegeneration in rats. Applied \& Translational Genomics 5: 30-32.

Scheepens, A., Bisson, J.F. \& Skinner, M. 2014. p-Coumaric acid activates the GABA-A receptor in vitro and is orally anxiolytic in vivo. Phytother. Res. 28(2): 207-211.

Schrader, A.J., Taylor, R.M., Lowery-Gionta, E.G. \& Moore, N.L.T. 2018. Repeated elevated plus maze trials as a measure for tracking within-subjects behavioral performance in rats (Rattus norvegicus). PLoS ONE 13(11): e0207804.

Teschendorf, P., Padosch, S.A., Spohr, F., Albertsmeier, M., Schneider, A., Vogel, P., Choi, Y.H., Bottiger, B.W. \& Popp, E. 2008. Time course of caspase activation in selectively vulnerable brain areas following global cerebral ischemia due to cardiac arrest in rats. Neurosci. Lett. 448(2): 194-199.

Thong-Asa, W. \& Tilokskulchai, K. 2014. Neuronal damage of the dorsal hippocampus induced by long-term right common carotid artery occlusion in rats. Iran J. Basic Med. Sci. 17(3): 220-226.

Vila-Ballo, A., Mas-Herrero, E., Ripolles, P., Simo, M., Miro, J., Cucurell, D., Lopez-Barroso, D., Juncadella, M., MarcoPallares, J., Falip, M. \& Rodriguez-Fornells, A. 2017. Unraveling the role of the hippocampus in reversal learning. J. Neurosci. 37(28): 6686-6697.
Winter, B., Juckel, G., Viktorov, I., Katchanov, J., Gietz, A., Sohr, R., Balkaya, M., Hortnagl, H. \& Endres, M. 2005. Anxious and hyperactive phenotype following brief ischemic episodes in mice. Biol. Psychiatry 57(10): 1166-1175.

Wolfer, D.P., Mohajeri, H.M., Lipp, H.P. \& Schachner, M. 1998. Increased flexibility and selectivity in spatial learning of transgenic mice ectopically expressing the neural cell adhesion molecule L1 in astrocytes. Eur. J. Neurosci. 10(2): 708-717.

Yan, B., He, J., Xu, H., Zhang, Y., Bi, X., Thakur, S., Gendron, A., Kong, J. \& Li, X-M. 2007. Quetiapine attenuates the depressive and anxiolytic-like behavioural changes induced by global cerebral ischemia in mice. Behavioural Brain Research 182(1): 36-41.

Animal Toxicology and Physiology Specialty Research Unit (ATPSRU)

Physiology Division, Department of Zoology

Faculty of Science

Kasetsart University

Bangkok 10900

Thailand

*Corresponding author; email: fsciwyth@ku.ac.th

Received: 21 May 2019

Accepted: 26 September 2019 